\title{
Liberal eller liberalistisk frihetssosiologi? Replikk til Mikael Carleheden og Michael Hviid Jacobsen
}

I sitt review-essay "Mod en sociologi om friheden" diskuterer Mikael Carleheden og Michael Hviid Jacobsen (heretter MC\&MHJ) min bok Frihet. Et essay om å leve sitt eget liv. Her er mitt tilsvar til mine skandinaviske kollegers tankevekkende kommentarer.

Det er mye MC\&MHJ og jeg er enige om. Vi er enige om at på tross av at frihet burde være et helt sentralt tema i sosiologien, befinner friheten seg $\mathrm{i}$ fagets periferi - og at det derfor er en viktig oppgave fremover å utvikle en teoretisk artikulert og empirisk forankret frihetssosiologi. Vi er også enige om viktige årsaker til frihetens svake posisjon. Og ikke minst er vi enige om hvordan spørsmålet om frihet bør stilles i sosiologien, nemlig som et spørsmål om "hvordan social orden er mulig under frihedens vilkår", eller, som jeg ville sagt, hvordan moderne samfunn muliggjør individets frihet. Det siste er kjerneoppgaven til det jeg kaller en liberal sosiologi.

MC\&MHJ stiller imidlertid også noen kritiske spørsmål til min bok. Deres hovedanklage er at min "liberale" sosiologi sklir over i en "ubegrunned liberalistisk" sosiologi. Hvis jeg forstår dem rett, er det særlig to punkter deres kritikk retter seg mot: mitt (teoretiske) frihetsbegrep, og min (empiriske) vurdering av frihetens betingelser i dagens vestlig-moderne samfunn.

MC\&MHJ kritiserer mitt frihetsbegrep for at det "nærmest sniger in en liberalistisk forforståelse av frihed" ved å underspille frihetens sosiale (intersubjektive) kjerne og i stedet prioritere individets fravær av begrensninger og beslutningsfrihet. For å imøtegå denne kritikken, vil jeg kort redegjøre for mitt frihetsbegrep - mens jeg underveis knytter noen kommentarer til MC\&MHJ. Logikken i mitt frihetsbegrep er at jeg begynner med en enkel kjerne og så legger på stadig nye lag med kompleksitet. 
På det første nivået forsøker jeg å definere hva som er frihetens vesen. Fra mitt handlingsteoretiske utgangspunkt definerer jeg i boken frihetens kjerne som ikke å møte begrensninger når vi på en rimelig bevisst måte forsøker realisere våre mål, altså handler. MC\&MHJ hevder at dette er for snevert, og jeg er enig. Siden jeg skrev boken, har jeg foretatt en standpunktendring og definerer nå frihetens kjerne som å lykkes med sine handlinger. Å lykkes med å realisere sine mål har både et negativt og et positivt aspekt: fravær av (indre og ytre) begrensninger og nærvær av (indre og ytre) ressurser. På dette nivået finner jeg derfor kritikken fra $\mathrm{MC} \& \mathrm{MHJ}$ om ensidighet langt på vei berettiget.

MC\&MHJ er nok allikevel ikke fornøyde. På det neste nivået konkretiserer jeg nemlig dimensjoner av handlingsfrihet, og her hevder jeg at de to viktigste er: ytre muligheter og beslutningsfrihet. Grunnen er at de til sammen utgjør kjernen i vår handlingskompetanse og gir oss det vi aller mest forbinder med frihet: kontroll over og ansvar for våre handlinger. MC\&MHJ hevder jeg på denne måten binder meg til et liberalistisk frihetsbegrep. Jeg er ikke enig. Allerede (idé)historisk er forholdet langt fra 1:1. Rett nok har liberalister siden Hobbes, Locke, Kant og Mill teoretisk og praktisk vært opptatt av individets ytre mulighetsrom, men det har jammen meg også kommunister, sosialister, anarkister, sosialdemokrater, feminister, homoaktivister og post-kolonialister. Og begrepet om beslutningsfrihet hører uansett hjemme i den kristen-eksistensialistiske tradisjonen fra Augustin, Pascal, Kierkegaard, Heidegger og Sartre, ikke primært den liberalistiske. Viktigere er at disse to frihetsbegrepenes primat er handlingsteoretisk begrunnet: De er mulighetsbetingelser for kontroll og ansvar. Alle frihetsforståelser må derfor inkorporere dem som sentrale. Å kalle disse to frihetsformene "liberalistiske", er derfor etter mitt syn ikke særlig treffende, de er langt mer allmenne.

Og selv om de skulle være liberalistiske, legger jeg på et tredje nivå til fire nye dimensjoner av handlingsfrihet (slik at jeg til sammen opererer med seks) som har det til felles at de spesifiserer substansielle kriterier for hvilke valg man må ta for å være frie: Man må være styrt av "høye" standarder (prinsippstyrt selvkontroll), utvikle og utfolde sine evner og ferdigheter (selvrealisering), handle på nye måter (kreativitet) og i hvert fall innimellom "slippe opp" og være i kontakt med sin "indre natur" (anarkistisk impulsivitet). Siden jeg inkluderer disse fire dimensjonene, som alle har et annet (idé)historisk opphav enn liberalismen, blir det enda mer uforståelig for meg at jeg anklages for å ha et endimensjonalt liberalistisk frihetsbegrep. Rett nok kritiserer MC\&MHJ meg for at jeg tolker disse fire frihetsformene " $i$ overensstemmelse" med de to første dimensjonenes logikk, men da de ikke presiserer hva de mener med det, er det vanskelig for meg å svare på den kritikken. La meg også tilføye at jeg kun prioriterer ytre muligheter og beslutningsfrihet handlingsteoretisk ("analytisk-deskriptivt"). "Analytisk-normativt" er jeg av den oppfatning at når et "gulv" av disse to er på plass, er det opp til - og mulig for - individet selv å avgjøre hvordan de seks ulike formene for frihet skal vektes i vedkommendes liv. 
Endelig føyer jeg en sosial dimensjon til mitt frihetsbegrep. Ja, mesteparten av min bok handler om denne. At MC\&MHJ kritiserer meg for ikke å operere med et sosialt frihetsbegrep, er derfor noe overraskende. De har imidlertid noe mer spesifikt i tankene, nemlig, med henvisning til Hegel og Honneth (hvor ble det av Habermas?), at friheten " $i$ sig selv er social eller intersubjektiv". Her er det en prinsipiell uenighet mellom oss. Jeg vil hevde at friheten i sitt vesen er et individuelt fenomen. Grunnen er enkel: Ettersom frihet kun kan tilskrives handlende aktører, og siden kun individer (enkeltpersoner) kan handle, kan kun individer være frie. Går vi "nedover" eller "oppover" i det ontologiske hierarkiet, finner vi ikke handlingskompetanse, og følgelig heller ikke frihet: Verken enkeltnerveceller i hjernen ("nedover") eller sosiale kollektiver ("oppover") kan i bokstavelig forstand handle, det kan bare naturlige personer. Allikevel er nok ikke uenigheten mellom oss i praksis så stor. Jeg er nemlig helt enig med MC\&MHJ i at sosiale relasjoner spiller en hovedrolle for friheten. Ja, konklusjonen i min bok er nettopp at når friheten har blitt demokratisert i Vesten (gått fra å være et eliteprivilegium til noe de fleste nyter godt av), så skyldes det at vi har bygget opp muliggjørende sosiale institusjoner - det jeg kaller positiv sosial frihet. Jeg er dog grunnleggende skeptisk til å knytte den teoretiske artikuleringen av dette poenget til Hegel og Honneth, slik MC\&MHJ ønsker. Anerkjennelsesrelasjoner er bare én av mange typer sosiale relasjoner som muliggjør individuell frihet, og Hegels og Honneths anerkjennelsesordener (intime relasjoner, kapitalistisk markedsøkonomi og demokratisk rettsstat) er bare tre av en rekke moderne institusjoner som muliggjør individets frihet. Etter mitt syn er det derfor langt mer fruktbart å utvikle modeller som fanger inn alle typer sosiale relasjoner som muliggiør frihet, samt å gjøre spørsmålet om hvilke institusjoner som forankrer friheten til et empirisk spørsmål. Ved å følge denne strategien, som jeg ikke kan se at skulle være "liberalistisk", har jeg kommet til 13 institusjoner (tuftet på 8 prinsipper for sosial organisering), samt redegjort for en rekke mekanismer (typer relasjoner) hvorigjennom disse 13 muliggjør individets frihet. Dermed kan jeg gi et langt mer utfyllende bilde av den moderne frihetens sosiale grunnlag enn hva MC\&MHJ kan med utgangspunkt i Hegel og Honneth. Og dermed kommer jeg også til andre konklusjoner om frihetens sosiale betingelser i dagens samfunn enn MC\&MHJ.

Det bringer meg over til den andre kritikken, nemlig at jeg ifølge MC\&MHJ også i mine empiriske analyser - og særlig konklusjoner - om frihetens betingelser i dagens samfunn sklir fra en liberal til liberalistisk sosiologi. I forbindelse med min tese om frihetens demokratisering kritiserer MC\&MHJ meg for det første for at det er "meningsløst" å telle frihet kvantitativt, og deretter for at jeg ikke ser hvordan den sosiale friheten blir fortrengt av den liberalistiske - noe det er en "kritisk" frihetssosiologis oppgave å påpeke.

Til det første er det å si at selv om heller ikke jeg tror på en enkel "frihetens aritmetikk", er det ikke meningsløst å snakke om "mer" eller "mindre" frihet. 
Også kritiske sosiologer som kritiserer frihetens ensidighet må jo hevde at vi har "mer" eller "for mye" av den liberalistiske og "mindre" eller "for lite" av den sosiale. Jeg mener også at mine analyser i sum klart peker i en bestemt "kvantitativ" retning: aldri for har så mange hatt så mye frihet på så mange områder i sine liv. Når jeg har kalt min bok et essay, er det imidlertid fordi jeg har prioritert det store bildet fremfor detaljerte empiriske indikatorer. En stor og viktig forskningsoppgave for en liberal frihetssosiologi er derfor å underbygge og nyansere - og eventuelt revidere - denne kvantitative påstanden gjennom mer inngående empiriske studier.

For det andre er jeg uenig med MC\&MHJ i at den liberale friheten fortrenger den sosiale. Ja, det er et hovedpoeng for meg å komme bort fra en slik diagnose av frihetens sosiale betingelser, som gjerne deles både av "kritiske" og "(ny)liberalistiske" samfunnsforskere (om enn med motsatte normative fortegn) - og som i mine øyne er noe av en samfunnsvitenskapelig klisje. Jeg delte sin tid en slik oppfatning (se mitt kapittel i antologien Frihet, redigert av Eriksen \& Vetlesen, som MC\&MHJ refererer til), men jo mer jeg har gravd meg ned i frihetens sosiale betingelser, jo mer overbevist er jeg blitt om følgende: Det er ikke liberalistisk ensidighet, men kombinasjonen av "liberalistisk" (formal) og "sosial" (substansiell) frihet som kjennetegner dagens vestlig-moderne samfunn. Vi har både rettigheter og materielle ressurser og tilgang til en rekke sosialt institusjonaliserte substansielle livsstiler, identiteter og livsprosjekter som gjør det mulig å leve en mengde forskjellige liv. Denne kombinasjonen er nøkkelen til å forstå frihetens demokratisering. Når jeg bruker så mye plass i boken på "forudsigelige og trættende" analyser av frihetens muligheter (jeg er delvis enig i karakteristikken), er det nettopp fordi jeg vil få frem dette: Aldri før har så mange biografiske alternativer - fra de "atomistiske" til "sosiale" - stått åpne for gjennomsnittssamfunnsmedlemmet. Selvfølgelig vil det oppstå konflikter mellom ulike friheter - noe jeg også legger stor vekt på i boken - men hvis mine sosiologiske analyser har noe for seg, har den liberalistiske friheten hovedsakelig supplert, ikke fortrengt, den sosiale.

I sum mener jeg derfor at min liberale frihetssosiologi ikke er liberalistisk verken på det begrepslige eller empirisk-diagnostiske nivået. Jeg mener også at mitt perspektiv gir en rikere og bedre begrepslig og empirisk forståelse av friheten enn rammeverket til Hegel og Honneth. Men jeg kan selvfølgelig ta feil. Min utfordring til mine to dyktige skandinaviske kollegaer er derfor at de utvikler sin egen frihetssosiologi og viser at et "sosialt" frihetsbegrep og en "kritisk" tilnærming bringer nye teoretiske innsikter og andre empiriske konklusjoner. Da ville de også gi et bidrag til å etablere en skandinavisk frihetssosiologi. Det er på høy tid at skandinaviske sosiologer åpner frihetens sorte boks. Det handler om å være på høyde med sin egen tid.

Gunnar Colbjørnsen Aakvaag

E-mail: g.c.aakvaag@sosgeo.uio.no 